\title{
Impact of Service Quality and Customer Satisfaction on Financial Performance with Customer Satisfaction as Moderation in BPD Kaltim Kaltara
}

\author{
H. Hairuzzaman \\ Doctoral Program of Economic and Business Faculty, Mulawarman University, Indonesia
}

\begin{abstract}
The study aims to investigate the effects of service quality and customer satisfaction on financial performance with customer satisfaction moderation in Bank Pembangunan Daerah Kalimantan Timur Kalimantan Utara. Based on a sample of 165 respondent and using structural equation modeling with PLS approach, and moderating effect. The results to show that service quality has a positive and significant effect on financial performance and customer satisfaction and shows that customer satisfaction has a positive and signicant effect on financial performance. Another result of this study indicate that work satisfaction is able to moderate the service quality to financial performance.Similarly, work satisfaction is also able to moderate customer satisfaction with financial performance. Thus it was found that financial performance can be achieved better through achieving work satisfaction for employees to create better service quality and customer satisfaction, esspecially in the baking industry. Finally, customer satisfaction partially moderate the relationship between service quality and customer satisfaction on financial performance. Moreover, the managerial and theoretical implications of the study along with limitations and suggestions for future research have also been discussed.
\end{abstract}

Keywords: Service quality, customer satisfaction, work satisfaction, financial performance

DOI: $10.7176 / \mathrm{EJBM} / 11-21-14$

Publication date:July $31^{\text {st }} 2019$

\section{Introduction}

Every organization has a interst in the best performance that can be produced by a systems series applied in the organization. Healhty organizations have employees who like to work in there, have pride in being part of the organization and are not wasy to move to other organizations or companies as simply, because offers such as better income and facilities. Employee do not want to lose the atmosphere, morale and pride of working in a company, that is not necessarily obtained elsewhere.

The role of human capital in an industry increasingly plays an important roe in facing increasingly fierce global. Gonzales (2007) defines human capital as a series of capabilities and competencies that each person has both through format education and experience, thus human capital is the ability, experience, competence, values, attitudes tha add value to organization.

Supporting these statements, Benevene (2010) states that human capital is formed by the attitudes, competencies, experiences and skills of internal members of an organization. Baron (2013) states that human capital is then referred to as knowledge, skills and experience of individuals and also their willingness to share the attributes that they already have to create value in the organization. Based on the various definitions that have been stated previously, basically all define human capital as a set of skills or competencies (Becker, 1993; Bontis, 1999; Baron, 2013) that provide added value to the organization. Thus, human capital in this study is defined as a set of skills, competencies, experiences, values, attitudes held by employees to create added value and improve organizational effectiveness and performance. The Service-Profit Chain forms the relationship between profitability, customer loyalty, and customer satisfaction, loyalty and employee productivity. Relationships in chains that must be considered as propositions are profit and growth enhanced through customer loyalty. Loyalty is a direct result of customer satisfaction. Satisfaction or satisfaction is largely influenced by the value of services provided to customers. Values are made by satisfied, loyal and productive employees. Employee satisfaction, in turn, mainly comes from services and policy support allowing employees to deliver results to customers and the finally as financial performance to company for the service provider concerned.

Work satisfaction in the banking sector has been systematically investigated in the 1990s, when a study from Davis (1992) and Asha (1994) showed that high work satisfaction among bank employees was positively correlated with low work stress, high job performance, intention low turnover and low psychological pressure. These findings were confirmed in Spector's (1997) study. Study Davis (1992) also revealed that work satisfaction is likely influenced by several factors, such as work environment, rewards offered at work, and family obligations and problems. In addition, it was found that the expectations of individual jobs tended to influence what they actually received from various faces of the work situation. Therefore, employers can use the information provided by the work satisfaction report to implement strategies for their subordinates' motivation and increased productivity. In addition, Mallik \& Mallik (1998) found that bank managers were more involved in work than sub-employees 
and staff, but experienced less work satisfaction. Walther (1988) has found that the adequacy of perceived communication in multi-branch banking organizations also affects employee productivity and work satisfaction.

The literature review shows that work satisfaction is a complex phenomenon, which does not occur separately, but depends on organizational variables, such as structure, size, salary, working conditions and leadership, all of which are organizational climate and culture (Boeyens, 1985). Organizational culture can be promoted to facilitate the achievement of work satisfaction and organizational goals. Cultural measurement can serve as a starting point in diagnosing and influencing these changes in the organization.

In the 1980s, the study of Schneider \& Reichers (1983) found a correlation between organizational climate and work satisfaction for employees in certain job positions, as well as the relationship between satisfaction and turnover. According to them that organizational culture is a combination of value systems and assumptions that cause organizations to run their business. McCormick and Ilgen (1987) suggest that measuring individual dimensions of work satisfaction allows researchers to identify environmental factors (climate variables) associated with certain dimensions of work satisfaction. During the 1990s, study Robbins (1993) suggested that, because the dimensions of work satisfaction are a component of an organization, work satisfaction is an evaluation of organizational culture. The latter describes work satisfaction as the difference between the results expected to be received by employees and those received.

Therefore in long-term the benefits are obtained that as the result, the banks profitability will be increased. Therefore the services quality in the banks and regard to the assessment of it is not only a strategy, but also the quality of superior service is exactly the distinction aspect between successful and inefficient banks (Khorshidi et al, 2014). On the other hand, assessment of services in the banks due to its evident relation with costs, profitability and customers' satisfaction is very important. Therefore, in order to reduce the costs, proper profitability and customers' satisfaction, considering the services quality is necessary (Hosseini et al, 2010).

\section{Literatur Review}

\subsection{Service Concepts}

Kotler (2000) put forward the notion of service (service) is as follows: "A service is any act or performance that one party can offer to another that is essentially intangible and does not result in the ownership of anything. Its production may or may not be tied to a physical product ". In this sense it is argued that a service is any action or performance offered by one party to another in principle intangibles and does not cause transfer of ownership. Production services may be bound or unbound to a physical product.

Stanton (2002) proposes the following definitions of service: "Service are identifiable, intangible activities that are the main object of a transaction designed to provide want-satisfaction to consumers. The services can be identified, intangible activity is the main object of a transaction designed to consider the satisfaction of the desires of the consumers. Through this definition we do not include support services that which supports the sale of other goods and services.

Further, in the opinion of Zeithaml and Bitner (2000) put forward the definition of services as follows: "Include all economic activites, the output is not a physical product or construction. as convenience, amusement, timelines, comfort or health) that are essentially intangible concerns of tis first purchaser ". Service is essentially all economic activity with output other than product in physical terms, consumed and produced at the same time, providing value added and intangible principle to its first buyer.

Based on the above definition it can be concluded that the service is basically something that has the following characteristics:

a. An intangible, but can meet the needs of consumers.

b. The service production process may use or not use the help of a physical product.

c. Services do not result in the transfer of rights or ownership

d. There is an interaction between service providers and service users

Identifying the nature of service experiences is recognised as being of primary importance in the shaping of an enhanced competitive position for industry; however service managers often have difficulty articulating the true nature of their service concept Fitzmimmons \& Fitzsimmons (2004). The definition of service concept is a fundamental part of the strategic advantage seeking processes of service design, service development and service innovation (Smart a\& Tax, 1997).

As services are driven to become more experiential and therefore increasingly intangible, the articulation of service concept invariably becomes more difficult but also more necessary (Biran \& Pedrosa, 1998). Definitions of service concept are of value to service managers in understanding what a service concept should be, but many do not go far enough in assisting practitioners in the arduous task of actually defining their individual service concept.

In reviewing the existing definitions of service concept, a number of core themes emerged from the varied definitions. The concept of value is at the centre of a number of service concept definitions and the service concept is seen by many as a means for the service provider to identify the value being delivered to customers and the 
value expected by customers from the organization. The term value is commonly used in association with monetary worth, however Ziethaml and Bitner (1996) define value is a individualized customer perception based on a composite judgements of a number of product/service attributes such as perceived quality, perceived costs; monetary or personal and other high level abstractions, intrinsic and extrinsic attributes such as prestige, accessibility and performance.

\subsection{Service Quality}

Lovelock and Wright (2005: 96) state that customers compare what they expect to receive with what they actually receive during the post-purchase stage in the process of purchasing services. They decide whether they are satisfied or not with the delivery of services and results, and they also make an assessment of the quality of services.

The concept of service quality and customer satisfaction is related to one another. Service quality is related to customer perceptions of quality based on long-term cognitive evaluation of corporate service delivery, while customer satisfaction is the customer's short-term emotional reaction to a particular service experience. Lovelock and Wright (2005: 96) further state that customers assess their level of satisfaction or dissatisfaction after using services. This information will be used by customers to update their perception of service quality. Attitudes toward service quality depend not only on customer experience, but people often base their judgment on the quality of services they have never used on word of mouth or from company advertisements. Customers must really use a service to find out whether they are satisfied with the results.

Cronin and Steven (1992) stated that service quality is the actual performance of services provided to customers. Mundie and Pirrie (2006: 86) state that service quality is a comparison between what services can do (what is service is supposed to do) and what services do (what does the service actually do). Lovelock and Wright (2005: 96) state that service quality is a customer's long-term cognitive evaluation of the service delivery of a company.

Kotler and Keller (2009: 143) define customer-centered quality and state quality is the totality of features and characteristics of a product or service that depends on their ability to satisfy expressed or implied needs. We can say that the seller has delivered quality when the product or service has met or exceeded customer expectations. Mundie and Pirrie (2006: 90) state that the quality of services can be formed from the dimensions of standardization namely hard standards and soft standards. A review of the emerging literature suggests that there appears to be relative consensus among marketing researchers that service quality and customer satisfaction are separate constructs which is unique and share a close relationship (Cronin and Taylor, 1994; Oliver, 1993). Most researchers in the services field have maintained that these constructs are distinct (Bitner, 1990; Carman, 1990; Boulding et al., 1993; Spreng and Mackoy, 1996).

\subsection{Customer Satisfaction}

Today the attention to customer satisfaction and dissatisfaction is getting bigger. The more parties are paying attention to this. The parties most directly related to customer satisfaction or dissatisfaction are consumer marketers, consumers, and consumer behavior researchers.

Tighter competition, where more and more producers are engaged in fulfilling the needs and wants of consumers, causes each company to place an orientation on customer satisfaction as the primary goal. This is reflected in the growing number of companies that include its commitment to customer satisfaction in its mission statement, and public relations release. Today it is increasingly believed that the key to winning the competition is to provide value and satisfaction to customers through the delivery of quality products and services at competitive prices.

In the context of product quality (goods and services) and customer satisfaction is reached the consensus that customer expectations play a important role as a comparative stasis in evaluating quality and satisfaction. According to Olsen \& Dover (quoted in Zeithaml, et al., 1993), customer expectations or expectations are the beliefs of customers before trying or buying a product or service, which is used as a standard or reference in assessing the performance of the product or service concerned. However, the conceptualization and operationalization of customer expectations remains a controversial issue, especially regarding the characteristics of specific expectations standards, the number of standards used, and the source of expectations. Each consumer may have several different pre-consumption expectations. In addition, different consumers may also apply different types of expectations for different situations.

The word satisfaction derives from that latin "satis" (meaning good enough, adequate) and "facio" (do or make). Decisions can be interpreted as "an attempt to accomplish something" or "make an adequate". Oxford Advanced Learner's dictionary (2000) describes satisfaction as "the good feeling that you have when you reach something or when something that you want to happen does happen"; "the act of fullfilling a need or desire"; and "an acceptable way of dealing with a complaint, a debt, an injury, etc". As long as these definitions seem so simple, yet so attuned to the context of consumer management and behavior, the term becomes so complex. Even Richard L. Oliver (1997) in his book "Satisfaction: A Behavioral Perpective on the Consumer" states that everyone 
understands what satisfaction is, but once asked to define it, nobody seems to know.

In a customer satisfaction literature review conducted by Giese \& Cote (2000), they identified 20 definitions referred to in customer satisfaction research over a 30-year period. Although these definitions vary (some are inconsistent with each other), the two experts from Washington State University have found similarities in terms of three main components: (1) customer satisfaction is a response (emotional or cognitive); (2) the response involves a particular focus (expectation, product, consumption experience, and so on); and (3) responses occur at any given time (after consumption, after product / service selection, based on accumulated experience and others). In short, customer satisfaction consists of components: a response to a particular focus that is determined at a given time.

Among the various variations available, so far the paradigm of disconfirmation is the most widely used and reference model (Churcill \& Surprenant, 1982; LaTour \& Peat, 1979; Oliver, 1999; Spreng, Mac Kenzie \& Olshavsky, 1996; Tse \& Wilton, 1988). This paradigm asserts that the satisfaction/satisfaction of after-sale is determined by the evaluation of the consumer against the difference between initial expectations (or other comparative standards) and perceptions of actual product performance after product use.

\subsection{Work Satisfaction}

The term "satisfaction" refers to the general attitude of an individual to his work. Someone with a high level of work satisfaction shows a positive attitude towards work. While some of the notions of Work satisfaction are quoted by Locke in Luthans (2011) that "Work satisfaction is pleasurable or emotional state positive resulting from appraisal of one's job or job experience", (Work satisfaction is a positive emotional expression or fun as a result of an assessment of a job or work experience). In accordance with social cognitive theory that work satisfaction is a cognitive process that interacts with the organizational context and ultimately results in organizational behavior. Work satisfaction reflects a person's feelings for his job. This can be seen in the employee's positive attitude towards work and everything faced in his work environment (Ciarniene, et al. 2010). Work satisfaction is a general attitude of an employee to his job (Robbins, 2006). Mathis and Jackson (2000) propose "work satisfaction is a positive emotional state resulting in one 's job experience", (Work satisfaction is a positive emotional statement that is the result of evaluation of work experience). In order to become more clear, employees will feel satisfied in working when aspects of their work and aspects support and vice versa if these aspects are not supportive, employees will feel dissatisfied.

Milton (1981) in Kreitner and Kinicki (2008) states that there are 7 (seven) dimensions of work satisfaction, namely as follows: (1) Work: the intrinsic interest of employees in accordance with employee duties; (2) Pay: an income payment system in accordance with perceptions of worth and fair, transparent and timely; (3) Promotion: promotion values honesty, honesty as a basis for promotion; (4) Recognition: appreciation for the success of the work, and criticism given if needed; (5) Work Conditions: working conditions according to occupational safety and health regulations; (6) Co-Worker: voluntary ability to help and friendliness; and (7) Company and Management (Company and Management): company regulations pay attention to employees, payment is appropriate, fair.

\subsection{Financial Performance}

Performance becomes one important thing for company management, because performance is theresult of work that can be achieved by a person or group of people in an organization, in accordance with their respective authorities and responsibilities in order to achieve the objectives of the organization in question, not violate law and in accordance with morals and ethics. Performance is a function of an organization's ability to acquire and use resources in various ways to develop competitive advantage. Performance is a basic concept that is general in nature, where this concept is usually understood implicitly, making it difficult to express explicitly. Performance related to certain concepts gives birth to specific approaches or measurements (Chakravarthy, 1986 and McGuire, 1993 in Yuliani, 2014: 9). Performance is also interpreted as a record of outcomes resulting from the function of a particular job or activity during a certain period.

Performance can be divided into financial and non-financial performance (Hansen and Mowen, 2005: 513). Financial performance is more focused on variables that are directly related to financial statements, while nonfinancial performance is ignored because it is considered difficult to measure and has a quite disturbing weakness, namely the inability to measure intangible assets and intellectual property resources. human. Financial and nonfinancial performance indicate whether the company's strategy, implementation of the strategy, and all company initiations improve the company's profits. By tracing a series of value-added activities through a series of indicators of causality that are important for the organization (from real activities to financial activities, from operational activities to strategic activities, from short-term activities to long-term activities, from local activities to global activities, or from activities business to corporate activities) decision makers will get a comprehensive picture of the performance of various company activities, but still in a series of strategies that are interrelated with each other. Company performance is tested in 3 (three) dimensions. First, the dimensions of company productivity, or 
processing inputs into output efficiently. Second, the dimensions of profitability, or the rate at which a company's income exceeds the costs incurred. The third dimension is the market premium, or the rate at which the company's market value exceeds its book value (Walker, 2001 in Iswati, 2007: 161). Currently in a competitive market, organizations strive to retain customers by relying on their satisfaction and loyalty, so the ultimate goal of the organization is to succeed in obtaining and maintaining customer repurchase intentions and ultimately financial performance (Egblopeali \& Aimin; 2011). Employees who are more satisfied are very hard workers and dedicated more to their work than those that are not satisfied. However, high customer satisfaction can be achieved if employees perform more than expectations, work more efficiently in teams and with their supervisors (Koys, 2003).

\section{Hypotheses}

Based on the previous explanations, this study aims to test the following models and hypotheses:

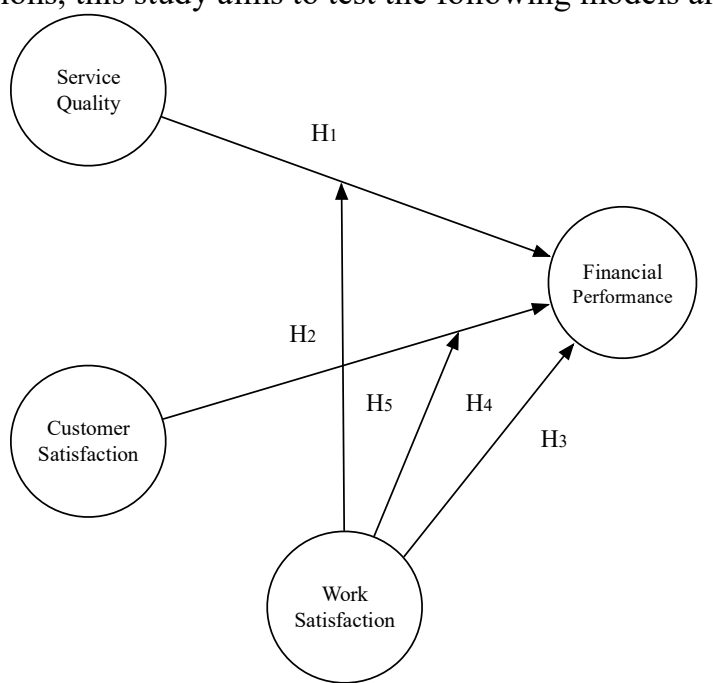

Figure 1. The Researh Conceptual Model and Findings

Hypothesis 1: Service quality has a positive effect on financial performance on BPD Kaltim Kaltara.

Hypothesis 2: Customer satisfaction has a positive effect on financial performance on BPD Kaltim Kaltara Hypotehsis 3: Work Satisfaction has a positive effect on financial performance on BPD Kaltim Kaltara Hypothesis 4: Work satisfaction has moderate service quality on financial performance on BPD Kaltim Kaltara. Hypothesis 5: Work satisfaction has moderate customer satisfaction on financial performance on BPD Kaltim Kaltara.

\section{Research Method}

This study was designed to analyze the relationship between the variables used, including the practice of marketing management, human resource management and financial management. This study uses quantitative approach. Thus, the logic is hypothetical verification. The approach begin deductive reasoning to derive the hypotheses, and then testing in the field. The conclution drawn based on empirical data. Thus there are more emphasis on quantitative research indices and empirical measurement. Quatitative researches to developing design is always a plan of activities that are a priority and definitive.

The population in this study were all 281 responden who have met the research criteria on PT. Bankaltim Kaltara. Determination of the samples was done by using Slovin method, with error rate of $5 \%$ to produce a sample of 165 respondents. The samples were taken by distributing a list of questionnaires with semantyc differential type to all respondents including customers of PT. Bankaltim Kaltara, at least in the last 2 years as the customers.

\section{Results}

The results of all respondents' responses are recapitulated and processed into a model of Structural Equation Modeling with the help of Smart PLS 3.2.8 software. The result of statistical analysis is then further processed up into the final result of the research. Smart PLS could be simultaneously to analyze the constructs formed with reflective and formative indicators, but in this research, all variables use reflective indicator. 
Table 1. Outer Loading Variable Indicator

\begin{tabular}{|c|l|c|c|c|c|}
\hline Construct & Indicator & Loading & Mean & STDEV & P Value \\
\hline \multirow{2}{*}{$\begin{array}{c}\text { Service Quality } \\
\text { (SRQ) }\end{array}$} & Reliability (SRQ1) & 0,764 & 0,762 & 0,055 & 0,000 \\
\cline { 2 - 6 } & Guarantee Security (SRQ4) & $\mathbf{0 , 7 7 3}$ & $\mathbf{0 , 7 6 7}$ & $\mathbf{0 , 0 4 7}$ & $\mathbf{0 , 0 0 0}$ \\
\cline { 2 - 6 } & Fast Respons (SRQ5)) & 0,773 & 0,771 & 0,116 & 0,000 \\
\hline \multirow{3}{*}{$\begin{array}{c}\text { Customer } \\
\text { Satisfaction (CUS) }\end{array}$} & Customer Service (CUS1) & 0,872 & 0,873 & 0,019 & 0,000 \\
\cline { 2 - 6 } & Reachable (CUS2) & 0,875 & 0,873 & 0,019 & 0,000 \\
\cline { 2 - 6 } & Recommend (CUS3) & $\mathbf{0 , 8 9 4}$ & $\mathbf{0 , 8 9 3}$ & $\mathbf{0 , 0 1 8}$ & $\mathbf{0 , 0 0 0}$ \\
\hline \multirow{4}{*}{$\begin{array}{c}\text { Work Satisfaction } \\
\text { (WST) }\end{array}$} & Ability to work (WST1) & 0,847 & 0,840 & 0,040 & 0,000 \\
\cline { 2 - 6 } & Job Promotion (WST2) & 0,737 & 0.735 & 0,046 & 0,000 \\
\cline { 2 - 6 } & Income Satisfaction (WST3) & 0,780 & 0,782 & 0,052 & 0,000 \\
\cline { 2 - 6 } & Mentoring Supervisor (WST4) & $\mathbf{0 , 8 6 4}$ & $\mathbf{0 , 8 6 5}$ & $\mathbf{0 , 0 2 1}$ & $\mathbf{0 , 0 0 0}$ \\
\cline { 2 - 6 } & Mentoring Supervisor (WST5) & 0,803 & 0,797 & 0,049 & 0,000 \\
\hline \multirow{3}{*}{$\begin{array}{c}\text { Financial } \\
\text { Performance (PRF) }\end{array}$} & Return On Asset (PRF1) & $\mathbf{0 , 8 1 4}$ & $\mathbf{0 , 8 0 8}$ & $\mathbf{0 , 0 5 3}$ & $\mathbf{0 , 0 0 0}$ \\
\cline { 2 - 6 } & Return On Investment (PRF2) & 0,755 & 0,751 & 0,066 & 0,000 \\
\hline
\end{tabular}

Based on the description of Table 1, it can be seen indicator of each construct that has dominant influence, on bold letters. Customer satisfaction (CUS) is dominated by Recommend (CUS3) as variable indicator, Financial Performance (PRF) is dominated by variable indicator of Contact Center 123 (COC), Service Performance (SEP) is dominated by Return on Asset (ROI) as variable indicator, Service Quality (SRQ) is dominated by indicator of Fast Respons (SRQ5) and Work Satisfaction (WST) is dominated by variable indicator of Mentoring Supervisor WST4).

As to see the validity and reliability of the structural capital in reflexive constructs, it can be seen the value in Table 2. as follows:

Table 2. Construct Reliability and Validity

\begin{tabular}{|l|c|c|c|}
\hline \multicolumn{1}{|c|}{ Cosntruct } & $\begin{array}{c}\text { Cronbach's } \\
\text { Alpha }\end{array}$ & $\begin{array}{c}\text { Composite } \\
\text { Reliability }\end{array}$ & $\begin{array}{c}\text { Average Bairance Extracted } \\
\text { (AVE) }\end{array}$ \\
\hline Service Quality & 0,864 & 0,814 & 0,593 \\
\hline Customer Satisfaction & 0,855 & 0,912 & 0,775 \\
\hline Work Satisfaction & 0,847 & 0,891 & 0,623 \\
\hline Moderating Effect 1 & 1,000 & 1,000 & 1,000 \\
\hline Moderating Effect 2 & 1,000 & 1,000 & 1,000 \\
\hline Financial Performance & 0,878 & 0,762 & 0,623 \\
\hline
\end{tabular}

Based on AVE values generated by all or all of the reflexive constructs that are above $>0.50$ so as to meet the requirements of convergent validity and reliability (Chin, 1998), (Chin, 2010b), (Hair et el., 2011), (Hair et.al, 2012).

Based on the value of Composite Reliability generated by all reflexive constructs that are above $>0.70$ so it can be concluded that all reflexive construction indicators are reliable or meet the reliability test (Chin. 1998), (Chin, 2010b), (Hair et el., 2011), (Hair et.al, 2012).

The next is the evaluation of the inner model in this study, presented in Table 3. as follows:

Table 3. Evaluation of R Square and R Square Adjusted Value

\begin{tabular}{|c|c|c|}
\hline Cosntruct & R Square & R Square Adjusted \\
\hline Financial Performance & 0,376 & 0,356 \\
\hline
\end{tabular}

Based on Table 3. it can be seen that $\mathrm{R}$ Square for inner model is equal to 0.376 and $\mathrm{R}$ Square is equal 0,356 or belong to a moderate category (Hair et al. 2011). Thus the results of this study are still close to the value of tolerance dan acceptance.

These results also show that in general the model of $37,6 \%$ is financial performance explained by service quality and customer satisfaction through moderation of work satisfaction, while the remaining $62,4 \%$ is explained by other variables as well as error factors, whether in the form of customer loyalty, marketing mix, and others.

The results of path analysis can be presented in the results of this study and the hypothesis testing of this study was conducted by looking at the pathways on a significant structural model. Significant pathways and effects can be seen in the partial path coefficient test, using the t test (t-test), or by looking at the significance level. Partial test results on the path coefficient on each path with the value of loading or coefficients can be seen in Figure 2. as follows: 


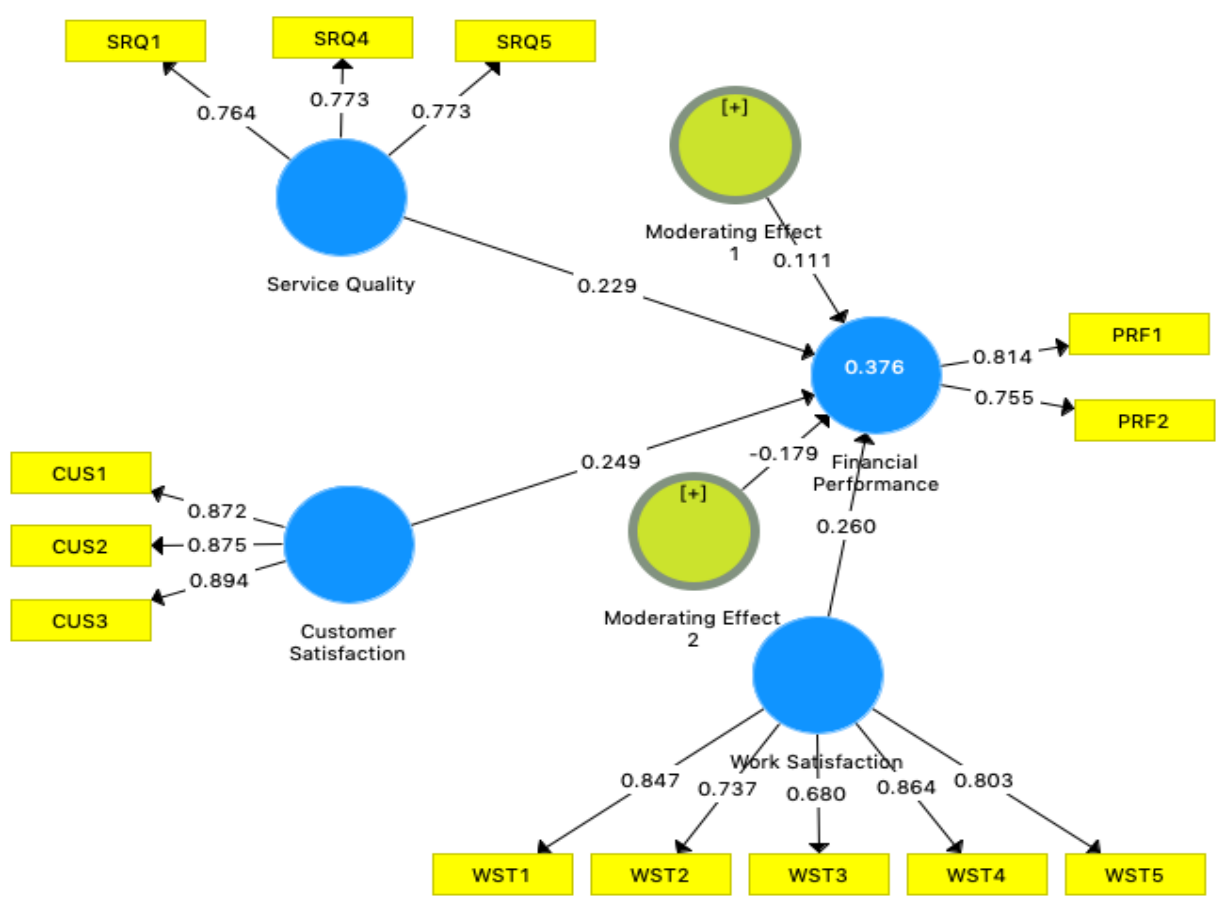

Figure 2. Confirmatoty Factors Analysis First Order Construct

Based on the results of the CFA it can be seen the direct and indirect effects between constructs, including the level of significance into Table 5. as follows:

Tabel 5. Summary of Research Hypotheses Test Result

\begin{tabular}{|c|c|c|c|c|c|c|}
\hline \multirow{2}{*}{$\begin{array}{l}\text { Exogenous } \\
\text { Veriables }\end{array}$} & \multirow{2}{*}{ Mederator } & \multirow{2}{*}{$\begin{array}{l}\text { Endogenous } \\
\text { Variables }\end{array}$} & \multicolumn{2}{|c|}{ Direct Effects } & \multirow{2}{*}{$\begin{array}{c}\mathrm{P} \\
\text { Value } \\
\end{array}$} & \multirow[b]{2}{*}{ Result } \\
\hline & & & Path Koef. & T-Statistic & & \\
\hline $\begin{array}{l}\text { Service } \\
\text { Quality }\end{array}$ & & $\begin{array}{c}\text { Financial } \\
\text { Performance }\end{array}$ & 0,229 & 2,410 & 0,017 & Positive \& Significant \\
\hline $\begin{array}{l}\text { Customer } \\
\text { Satisfaction }\end{array}$ & & $\begin{array}{c}\text { Financial } \\
\text { Performance }\end{array}$ & 0,249 & 2,880 & 0,004 & Positive \& Significant \\
\hline $\begin{array}{l}\text { Work } \\
\text { Satisfaction }\end{array}$ & & $\begin{array}{c}\text { Financial } \\
\text { Performance }\end{array}$ & 0,260 & 2,219 & 0,027 & Positive \& Significant \\
\hline & $\begin{array}{l}\text { Moderating } \\
\text { Effect } 1\end{array}$ & $\begin{array}{c}\text { Financial } \\
\text { Performance }\end{array}$ & 0,111 & 1.989 & 0,046 & Positive \& Significant \\
\hline & $\begin{array}{l}\text { Moderating } \\
\text { Effect } 2\end{array}$ & $\begin{array}{c}\text { Financial } \\
\text { Performance }\end{array}$ & $-0,179$ & 2,414 & 0,016 & Negative \& Significant \\
\hline
\end{tabular}

\section{Explanation:}

$\mathrm{H}_{0}$ accepted if $-1.96>=\mathrm{Z}<=1.96$ (Not significant)

$\mathrm{H}_{1}$ accepted if $\mathrm{Z}>1.96$ or $\mathrm{Z}<-1.96$ (Significant)

$P$ Values $>0.05$ (Not Significant)

$P$ Values $<0.05$ (Significant)

Based on the result of hypothesis research test, it can be explained that all variable have positive and significant effect to finance performance, except moderating effect 2 has negative and significant effect.

\section{Conclution}

This result has provided the first empirical insight, namely the direct influence of variables with moderator. In first finding.that service quality has a positive and significant effect on financial performance. The results obtained from structural equations modeling and studying the hypotheses indicate that services quality has positive, direct, meaningful and significant effect on financial performance of Keshavarzi bank branches of Khuzestan province. Namely with recovery of the services quality, the financial performance of Keshavarzi bank branches of Khuzestan province is increased. This result of current research has conformity with the research results of Keisidou \& et al (2013). This situation shows that through good service quality, it will be able to show good attention to consumers so that consumers will become more loyal and financial performance will increase. This result shows that through security gurus, then realiability and fast respond can result in a better financial performance. This result is in line with the opinion of Kotler (2000), where service is a form of service offered to other parties and in the form of an intangible, but can be interpreted as a benefit. Likewise in line with the opinion of Stanton (2002), which states 
that intangible services are the main object of a transaction designed to provide satisfaction desired by consumers. These findings are in line with the opinions expressed by Lovelock and Wright (2005) where through service quality, customers will be able to feel the realization of desired expectations during post-purchase so that they will decide on achieving a good service quality.

In second finding that customer satisfaction has a positive and significant effect on financial performance. Among the various variations available, so far the paradigm of disconfirmation is the most widely used and reference model (Churcill \& Surprenant, 1982; LaTour \& Peat, 1979; Oliver, 1999; Spreng, Mac Kenzie \& Olshavsky, 1996; Tse \& Wilton, 1988). This paradigm asserts that the satisfaction/satisfaction of after-sale is determined by the evaluation of the consumer against the difference between initial expectations (or other comparative standards) and perceptions of actual product performance after product use. Customers with very high levels of satisfaction will be more loyal, loyal to a company longer and will automatically spend more money on the company (Williams \& Naumann, 2011). Srivastava et all. (1998) suggested that high customer satisfaction leads to accelerated cash flow, increased cash flow volume, and reduced risk associated with cash flow. Increased customer leads to satisfaction with increasing cash flow and reducing risk associated with cash flows (Srivastava et all., 1998). Customer satisfaction leads to higher future income (Rust and Zahorik, 1993; Rust et all, 1995) and reduce operating costs (Srivastava et al, 1998). Satisfaction chains are another model that is useful for understanding the expected relationship between satisfaction and financial performance (Anderson and Mittal, 2000). This model argues that performance leads to increased customer satisfaction, which results in higher profits. Currently in a competitive market, organizations strive to retain customers by relying on their satisfaction and loyalty, so the ultimate goal of the organization is to succeed in obtaining and maintaining customer repurchase intentions and ultimately financial performance (Egblopeali \& Aimin; 2011).

In third finding that work satisfaction has a positive and significant efffect on financial performance. This resut in line with the opinion of of James-Hesket et al (1994) made an important contribution to the discussion of the effects of good service on customers, in their work on the chain of service benefits. In their work, customer satisfaction is seen as a function of the value created by customers through the quality of services provided by the company and its employees. This satisfaction is seen as contributing greatly to the survival of the customer and subsequently, the ability to generate profits. Employees who are more satisfied are very hard workers and dedicated more to their work than those that are not satisfied. However, high customer satisfaction can be achieved if employees perform more than expectations, work more efficiently in teams and with their supervisors (Koys, 2003). However, on the other hand, some studies suggest that regressing financial performance on employee satisfaction yields statistically insignificant results thus suggesting no direct relationship exists between employee satisfaction and financial performance (Matzler and Renzl (2007), Printchard and Silvestro (2005), Silvestro (2002), and Keiningham (2006). According to Wiley (1991), the relationship of employee satisfaction and business outcomes is insignificant. Analogous results were suggested by Bernhardt et al. (2000) that the correlationbetween worker satisfaction and financial outcome was "virtually nonexistent". This insignificant direct relationship may be explained by the fact that the relationship between employee satisfaction and financial performance might be indirect. According to the service-profit chain, if employees are satisfied then they will provide good services to the customer and in turn customers will be satisfied and loyal to the company and make purchases repeatedly and show the positive word of mouth behavior that will leads toward the high financial returns (Koys, 2003). Hence, there is an indirect relationship between employee satisfaction and financial performance and this indirect relationship is likely to be mediated by customer satisfaction

In fourth finding that moderate effect 1 has a postive and significant effect, thus showing work satisfaction able to moderate service quality on financial performance and at the same time able to answer the fourth hypothesis. Service quality has a close relationship with customer satisfaction. Quality as the overall characteristics and characteristics of a product or service that supports the ability to satisfy needs (Kotler, 2003). Quality gives an impetus to the customer to establish a strong relationship with the company. In the long run these bonds allow companies to understand carefully the expectations of customres and their needs. So that it will be alb to have an impact on the increasi in financial performance. Because services are activities that are intangible and that require interaction between customers and service providers, then service providers should focus on fulfilling the needs and desires of customers, especially on service quality so that customers are satisfied and have high loyalty to service providers. To support this, it is necessary to increase employee job satisfaction. Increased employee job satisfaction is expected to improve service quality (Hartline and Ferrel, 1996, Kotler and Armstrong, 1998). High job satisfaction is expected to be able to improve the quality of service that is also high so as to be able to attract customers as much as possible and financial performance will also improve. Customer satisfaction is a post purchase attitude formed through mental comparison of the quality a customer expects to receive from an exchange, and the level of quality the customer perceives actually receiving. Customer satisfaction results in behavioral outcomes such as customer retention, commitment, creation of a mutually rewarding bond between the user and the service provider, increased customer tolerance for services and products failures, positive word-of-mouth advertising about the organization, increased future customer spending, and it might result in more selling, 
attracting new customers, lowering costs, and greater profitability.

In fifth finding that moderate effect 2 has a postive and significant effect, thus showing work satisfaction able to moderate customer satisfaction on financial performance, and at the same time able to answer the fifth hypothesis. High customer satisfaction is expected to be able to genarete and increase customre loyalty to service provider intitutions. Customer loyalty is the customer's actions related to favorable attitudes and behaviour after receiving services. It might be well accepted nowadays that intensive competitiveness, dynamic business environments and the increasing of customer powers have pushed firms toward the customerfocused strategy (Perera, Harrison, \& Poole, 1997). As a result, excellent business process and intangible assets such as brands, customer satisfactions and powerful human resources might become the most essential sources for sustainable competitive advantages (Roos \& Roos, 1997; Teece, 2007; Wang \& Ahmed, 2007). These fundamental trends together with the invisible and hard-to-observe characteristics of qualitative/nonfinancial measures have raised the questions of whether nonfinancial measures such as customer satisfaction, job satisfaction do have the real and significant effects on firm performance and how they do it. There are several reasons why nonfinancial measures are useful as the supporters for financial measures when explaining the firm's performance. Customer satisfaction was related to financial performance by customer retention which secured future revenues, established a better comparative position in the banking industry, increased customer loyalty and its ensuing advantages for stakeholders and all these were mirrored in financial performance.

\section{References}

Anderson, E. W., \& Mittal, V. (2000). Strengthening the satisfaction-profit chain. Journal of Service research, 3(2), 107-120.

Asha, C.B. (1994). Job Satisfaction Among Women in Relation to Their Family Environment. Journal of Community Guidance and Research, 11(1), 43-50.

Baron, Angela and Michael Amstrong. (2013). Human Capital Management, PPM: Jakarta.

Becker, Gary Stanley. (1993). Human Capital: a theoretical and empirial analysis, with special reference to education 3rd edition, The University of Chicago Press, Ltd, London.

Bernhardt, K. L., Donthu, N., \& Kennett, P. A., (2000). "A longitudinal analysis of satisfaction and profitability," Journal of Business Research, 47: 161-171.

Bitner, M. J. (1990). Evaluating Service Encounters: The Effects of Physical Surroundings and Employee Responses. Journal of Marketing, 54(2), 69-82.

Bitran, G. \& Pedrosa, L. (1998). "A structured Product Development Perspective for Service Operations", European Management Journal, Vol. 16 No. 2 pp. 169-89.

Boeyens, M.J. (1985). The Synergistic Nature of Organizational Climate, Unpublished Doctoral Thesis.

Bontis, Nick. (1999). "Intellectual Capital: An Exploratory Study that Develops Measures and Models." Management Decision Vol. 36 No. 2, hal 63-76.

Boulding, W., Kalra, A., Staeling, R., and Zeithaml, V. A. (1993). A Dynamic Process Model of Service Quality: From Expectation to Behavioral Intentions. Journal of Marketing Research, 30(1), 7-27.

Benevene, P., Cortini, M., (2010). Interaction between structural capital and human capital in italian npos: leadership, organizational culture and human resource management. J. Intellect. Cap. 11, 123-139.

Carman, J. M. (1990). Consumer Perceptions of Service Quality: An Assessment of the SERVQUAL Dimensions. Journal of Retailing, 66(1), 33-55.

Cronin J. Joseph, Jr., \& Steren A. Taylor. (1992). Measuring Service Quality: A reexamination and Extension, Journal pf Marketing, 56 (July): 53-68

Churchill Jr., G.A. and Surprenant, C. (1982) An Investigation into the Determinants of Customer Satisfaction. Journal of Marketing Research (JMR), 19, 491-504.

Davis, R. (1992). Person-Environment Fit and Job Satisfaction. In: Cranny, C.J., Smith, P.C. and Stone, E.F. (Eds.). Job Satisfaction, 69-880, Lexington Books, New York

Egblopeali, A. Y. and Aimin, W. (2011). Reoseurly on Effects of Corporate Image, CustomerSatisfaction and Switching Cost on Customer Loyalty in Togolese Telecommunication Companies, Proceedings of the 7th International Conference on Innovation \& Management.

Fitzsimmons, J. A. \& Fitzsimmons M. J., (2004). Service Management: Operations, Strategy and Information Technology, McGraw-Hill: London.

Gonzalez S,M. and Tacorante D.V. (2007). A new approach to the best practices debate: are best practices applied to all employees in the same way?, International Journal of Human Resource Management 15 (1): 56-75.

Koys, D. (2003). How the achievement of human-resources goals drives restaurant performance," Cornell Hotel and Restaurant Administration Qualrterly, 44(1): 17-24.

Hartline, Michael, D., \& O.C. Ferrel. (1996). The Management of customer Contract Service Employees: An Empiris Investigation, Journal of Marketing, Vol. 60 (October): 52-70.

Heskett, James L.; Jones, Thomas O.; Loveman, Garry W.; Sasser, W. Earl; and Schlesinger, Leonard A. (1994). 
Putting the Service-Profit Chain to Work. Harvard Business Review, March-April, (164-174).

Hosseini, M. Ahmadinejad, M. Ghaderi, S, (2010). Studying and assessment of the services quality and its relation with customers satisfaction, case study: Tejarat bank, commercial studying, No.42, pages 88-97.

Keiningham et al. (2006). "Reexamining the link between employee satisfaction and store performance in a retail environment," International Journal of Service Industry Management, 17(1): 51 - 57.

Keisidou, E., Sarigiannidis, L. and Dimitrios, I. Madition, (2013), Customer satisfaction, loyalty and financial performance A holistic approach of the Greek banking sector, Department of BusinessAdministration, Technological Educational Institute of Kavala, Kavala, Greece, andEleftherios I. ThalassinosDepartment of Maritime Studies, University of Piraeus, Piraeus, Greece, Vol. 30, No. 4, pp.259-288.

Khorshidi, Gh. Naghash, A. Mohammadian, M. (2014), assessment and analysis of the services quality gap according to the hierarchy service quality model in keshavarzi bank, journal of economic researches, volume 14, No.1, pages 151-168.

Kotler, Philip dan Gary Armstrong, (2003), Dasar-Dasar Pemasaran, Jilid 1, Edisi Sembilan, Indeks Gramedia, Jakarta.

LaTour, Stephen A., and Peat, Nancy C. (1979), "Conceptual and Methodological Issues in Consumer Satisfaction Research," in Advances in Consumer Research, (Vol. 6), ed. William L. Wilkie, Ann Arbor: Association for Consumer Research, 431-440.

Mallik, V., \& Mallik, P.K. (1988). Job Involvement Vis-à-Vis Job Satisfaction of Bank Employees: A Case Study. Management Accountant, 33, 365-368.

Matzler, K.., Renzl, B., (2007). "Assessing asymmetric effects in the formation of employee satisfaction," Tourism Management, 28 (4): 1093-1103.

McCormick, E.T. \& Ilgen, D. (1987). Industrial and Organizational Psycology ( $8^{\text {th }}$ Ed). Routlege, London.

Oliver, R. L. (1993). Cognitive, Affective, and Attribute Bases of the Satisfaction Response. Journal of Consumer Research, 20, 418-430.

Oliver, R.L. (1999) Whence Consumer Loyalty. Journal of Marketing, 63, 33-34.

Perera, S., Harrison, G., \& Poole, M.(1997). Customer-focused manufacturing strategy and the use of operationsbased non-financial performance measures: A research note. Accounting, Organizations and Society, 22(6), $557-572$.

Philip Kotler, (2000), "Principle of Marketing”, Prentice Hall of India Private Limited, New Delhi 110001.

Pritchard, M., \& Silvestro, R. (2005). "Applying the service profit chain to analyse retail performance: The case of the managerial strait-jacket?” International Journal of Service Industry Management, 16(4): 337 - 356.

Roos, G., \& Roos, J. (1997). Measuring your company's intellectual performance. Long Range Planning, 30(3), 413-426

Silvestro, R. (2002). "Dispelling the modern myth: Employee satisfaction and loyalty drive service profitability," International Journal of Operations \& Production Management, 22(1): 30 - 49.

Spreng, R. A., and Mackoy, R. D. (1996). An empirical examination of a model of perceived serviced service quality and satisfaction. Journal of Retailing, 72(2), 201-214.

Srivastava, R. K., Shervani, T. A., \& Fahey, L. (1998). Market-based assets and shareholder value: a framework for analysis. The Journal of Marketing, 2-18.

Robbins, S.P. (1993). Organizational Behaviour, Concepts, Controversies and Applications. (6th Ed.). Englewood Cliffs. Prentice- Hall, New Jersey.

Rust, R. T., \& Zahorik, A. J. (1993). Customer satisfaction, customer retention, and market share. Journal of retailing, 69(2), 193-215.

Rust, R. T., Zahorik, A. J., \& Keiningham, T. L. (1995). Return on quality (ROQ): Making service quality financially accountable. The Journal of Marketing, 58-70.

Schneider \& Reichers. (1983). On Etiology of Climates, Personnel Psycology, 36, 19-37.

Stuart, F. I., \& Tax, S. (1997). Towards an Integrative approach to designing service experiences; lessons learned from the theatre, Journal of Operations Management, Vol. 22 pp $609-627$.

Taylor, S. A., and Cronin, J. J. (1994). Modelling Patient Satisfaction and Service Quality. Journal of Health Care Marketing, 14(1), 34-44.

Wang, C. L., \& Ahmed, P. K. (2007). Dynamic capabilities: A review and research agenda. International Journal of Management Reviews, 9(1), 31-51.

Walther, J.B. (1988). Communication Satisfaction in The Bank: An Audit Evaluation. Journal of Business Communication, 25(3), 79-86.

Wiley, J. W. (1991). "Customer satisfaction: a supportive work environment and its financial costs," Human Resource Planning, 14(2):117-127.

Williams, P. and Naumann, E. (2011) Customer Satisfaction and Business Performance: A Firm-Level Analysis. Journal of Services Marketing, 25, 20-32.

Ziethaml, V. and Bitner, M. J., (1996). Services Marketing, McGraw Hill, New York: NY. 